\title{
PEMANFAATAN APLIKASI VIDEO CALL WHATSAPP PADA TPQ MIFTAUL ULUM GEDONGKUNING YOGYAKARTA
}

\author{
Naning Ma'rifatul Faiqoh \\ UIN Sunan Kalijaga Yogyakarta \\ naningfaiqoh@gmail.com
}

\begin{abstract}
Research on the use of the whatsaap video call application in the Al-Quran education park Miftahul Ulum Gedongkuning Yogyakarta using qualitative descriptive research methods, conducting interviews with 6 informants, observation, and literature study. The research objectives: 1) to determine the constraints of whatsaap video calls in the activities of the TPQ Miftahul Ulum Yogyakarta students 2) to determine the impact of whatsaap video calls in the activities of the TPQ Miftahul Ulum Yogyakarta students. The results of the study were 1) Obstacles to whatsaap video calls in the activity of reciting TPQ Miftahul Ulum Gedongkuning students from the results of interviews by several informants that the lack of time to recite the recitation and when reciting took place sometimes the signal was interrupted which caused the sound to falter and even stop so that a signal was available or educator / ustadz / ah turn off the camera feature so that the signal is focused only on the sound. 2) Two-way communication and lots of support makes this activity run well, and really helps the santri guardians in the development of the Koran for children. This activity can also introduce children in a positive way, that the whatsaap video call media can be used in the realm of learning and the guardians of the students feel that the child is more focused on the Koran, after
\end{abstract}


reading the child is reminded of inappropriate / wrong readings and the child feels responsible because at the end of the session children are reminded to read the previous / next page and will be checked for tomorrow's meeting.

Keyword: Whatsaap Video Call Application, Al-Quran Education Park, Yogyakarta.

\section{PENDAHULUAN}

Nabi Muhammad terpilih menjadi utusan dan penyampai firman Allah yakni Al-Quran sebagai petunjuk bagi Jin dan Manusia. kebenaran Al-Quran bersifat mutlak serta wajib diimani oleh bagi umat muslim, begitu banyak isyarat-isyarat yang Allah selipkan pada Al-Quran, diantaranya tentang ilmu pengetahuan, Al-Quran terdapat ribuan ayat yang mengajak manusia dalam mengembangkan ilmu pengetahuan. Sepertihalnya Ayat pertama kali turun yaitu surat al-Alaq. Dalam ayat tersebut mengajarkan pentingnya mencari dan menggali ilmu pengetahuan. ilmu pengetahuan akan semakin berkembang dengan proses pembelajaran yakni adanya interaksi antara pendidik dan peserta didik.

Sejak masuknya Islam ke bumi nusantara, tanpa disadari proses pembelajaran Al-Quran mulai berjalan oleh para penyebar agama Islam. Dalam prosiding Al-Hidayah Pendidikan Agama Islam, Institut Ilmu Quran meneliti dari sekian banyak warga Indonesia 65\% diataranya buta huruf Al-Quran . ${ }^{1}$ Metode mendalami Al-Quran ada bermacam-macam, dari metode klasik seperti al Bagdadi, Iqro', Ummi, Tilawati hingga metode modern yang diinovasi dengan teknologi, metode-metode tersebut lahir agar memudahkan para pembelajar Al-Quran, semua metode ini sangat menarik dan bagus untuk anak².

Banyak ayat-ayat Al-Quran yang dapat membawa dalam kesejahteraan dunia akhirat tentunya dengan dorongan agar manusia menggunakan dan memanfaatkan segala apa yang dimilikinya. ${ }^{3}$. Dalam

\footnotetext{
1 Muhammad Dony Purnama, M Sarbini, Ali Maulida.,(2019), Implementasi Metode pembelajaran AlQuran Bagi Santri Usia Tamyiz Di Kuttab Al-Fatih Bantarjati Bogor, Prosiding Al-Hidayah Pendidkan Agama Islam, h, 180.

2 Akhmad Djul Fadli, Rahendra Maya, dan Sarifudin, (2018), Upaya Orangtua dalam Meningkatkan Minat Baca Al-Qu'an Anak dalam Keluarga (Studi di Masjid Umair bin Abi Waqosh Kampung Batu Gede RT 004 RW 007 Desa Cilebut Barat Kecamatan Sukaraja Kabupaten Bogor), Prosa PAI: Prosiding Al-Hidayah Pendidikan Agama Islam, hlm, 94.

${ }^{3}$ Ling Misbahuddin, Dimensi Keilmuan Dalam Al-Qur'an, Jurnal at Taqaddum, Vol 6, No 2, (2014), h, 348.
} 
surat Luqman ayat 13 yang artinya 'Dan (ingatlah!) ketika luqman berkata kepada anaknya, ketika dia memberikan pelajaran kepadanya, "wahai anakku! Jangan engkau mempersekutukan Allah SWT, sesungguhnya mempersekutukan (Allah) adalah benar-benar kedzaliman yang besar", cerita Luqman diabadikan di dalam Al-Quran karena senantiasa mengingatkan dan menasehati anaknya. Ketika anak dari buaihan selalu ditanami kebaikan oleh orang tuanya, maka kebaikan akan ditunainya. namun sebaliknya, jika sejak dini anak disuguhkan dengan hal dengan hal yang buruk, maka sersor otak akan merekam dan akan menjadi ingatan abadi pada anak sehingga anak akan meniru dan berperilaku apa yang sering dia rekam. Jadi apapun yang ditanam orang tua pada tumbuh kembang anak, maka orang tua pasti menuai hasilnya. Orang tua yang beriman diperintahkan oleh Allah SWT agar memelihara keluarganya dari api neraka, maka dengan cara memberikan pendidikan yang baik, orang tua akan mendapat menyelamatkan anak-anaknya ${ }^{4}$.

Sejak tahun 2000 teknologi semakin merangkak cepat dan membawa dampak besar pada banyak elemen, dengan teknologi semua hal yang nampak sulit menjadi terlihat mudah seperti halnya keranjang tidur/ meja makan yang berhasil disederhanakan seperti origami yang menjadi inovasi bagi peralatan para astronot. Dalam dunia pendidikanpun tidak luput dari teknologi, berbagai macam hal ditawarkan oleh teknologi agar kualitas pendidikan semakin bagus. Teknologi menjadi penunjang dalam pendidikan seperti buku, dulu banyak orang rela membawa tumpukan buku ketika mau mengkajinya, namun sekarang semua literatur buku dapat diringkas dalam sebuah alat teknologi yang ringan, mudah dibawa kemanapun dan dalam kondisi apapun, sehingga menjadi peluang dalam mengembangkan dan menumbuhkan potensinya. Internet diantara dari hasil teknologi informasi yang telah memiliki banyak aplikasi seperti media sosial yang kini sangat berpeluang dalam mencari data, menjalin silaturahim secara online $e^{5}$.

Banyaknya aplikasi berbasis penyampaian informasi telah banyak disediakan di Aap Store diantaranya adalah WhatsApp, layanan fitur yang disediakan WhatsApp semakin hari semakin lengkap, Whats $A p p$ merupakan salah satu aplikasi berbasis penyampaian informasi yang

\footnotetext{
${ }^{4}$ Septiyanti Rizka Fadhlia, Syuaebatul Islamiyah, Kusmia, Tiara Ayu Saventy, dan Zakia Mawaddah. Konsep Al-Qur'an tentang Kecerdasan Anak Dalam Q.S. Luqman Ayat 12- 19, At-Tajdid: Jurnal Ilmu Tarbiyah Universitas Ibnu Khaldun Bogor, (2018), hlm, 110.

5 Trisnani, Pemanfaatan Whatsapp Sebagai Media Komunikasi Dan Kepuasan Dalam Penyampaian Pesan Dikalangan Tokoh Masyarakat, Kominfo: Jurnal Komunikasi, Media dan Informatika, Vol 6, No 3, (2017), h, 2.
} 
sangat populer dan berbagai lapisan masyarakat nusantara telah menjadi pengguna dari Whats $A p p$.

Dalam tesis saudara Andi Miladiyah mengatakan, separo dari pengguna youtube memakai Whatsaap Messenger, user whatsaap sebanyak 60\% dan Facebook sebesar 54\%, user facebook juga mayoritas berbagi fotpun melalui whatsaap sekitar 75\% sementara Facebook sekitar $49 \%$ saja $^{6}$.

400 juta pengguna aktif tercatat pada februari 2013, dan pada bulan september 2015 user aktif telah mencapai 900 juta, perkembangan yang sangat pesat itu juga hasil akusisi facebook untuk whatsaap senilai 19 Miliyar dollar Amerika ${ }^{7}$.

Novel Coronavirus Pneumonia atau NCP merupakan nama asal yang diberikan oleh Komisi Kesehatan Nasional China, atau yang sering kita dengar virus corona, virus ini pertama muncul di negara China tepatnya di kota Wuhan. World Healty Organization pada selasa 11/2/2020 Covid-19 menjadi nama resmi corona, Pertama kali Coronavirus diidentifikasi di kota Wuhan China pada 31 Desember 2019. Covid-19 berhasil tersebar hingga pada fase pandemi, Indonesiapun tidak luput dari hal tersebut. Pasien pertama kali yang terdeteksi Covid-19 berasal dari Depok, Jawa Barat, kabar tersebut langsung diumumkan oleh presiden Joko Widodo di Istana Kepresidenan, Jakarta, Senin (2/3/2020) kemarin?. Gubernur Daerah Istimewa Yogyakarta Sri Sultan Hamengkubuwono $\mathrm{X}$ memutuskan status tanggap darurat bencana terkait wabah virus corona atau Covid-19, status yang ditetapkan lewat surat bernomor $65 / \mathrm{KEP} / 2020$ mulai berlaku pada hari, Jumat (20/3/2020) hingga 20 Mei $2020^{10}$.

Dalam surat penetapan status tanggap darurat virus corona, HB X juga menugaskan Wakil Gubernur Daerah Istimewa Yogyakarta untuk

\footnotetext{
${ }^{6}$ Andi Miladiyah, Pemanfaatan Whatsapp Messenger Info Dalam Pemberian Informasi Dan Peningkatan Kinerja Pada Sub Bagian Program Pemerintah Provinsi Sulawesi Selatan, Tesis: Ilmu Komunikasi Fakultas Ilmu Sosial dan Ilmu Politik Univeristas Hasanuddin Makassar, (2017), h, 6 .

7 https://www.academia.edu/37212652/Mobile_Computing_System_WhatsApp_pdf. diakses pada tanggal 11 april 2020.

8 https://www.kompas.com/tren/read/2020/02/12/063200865/ini-alasan-whomemberi-nama-resmi-covid-19-untuk-virus-corona?page $=$ all. diakses pada tanggal 12 April 2020.

https://www.google.com/amp/s/amp.kompas.com/nasional/read/2020/03/03/0631 4981/fakta-lengkap-kasus-pertama-virus-corona-di-indonesia. diakses pada 12 April 2020.

10 https://yogyakarta.kompas.com/read/2020/03/20/16245451/sultan-hb-x-tetapkanstatus-tanggap-darurat-virus-corona-di-diy, diakses pada 12 April 2020. 
mengambil langkah yang diperlukan untuk mencegah dan menangani dampak buruk yang ditimbulkan, termasuk diantaranya adalah kegiatan penyelamatan, dan evakuasi, isolasi, perlindungan, pengurusan, penyelamatan, serta pemulihan korban virus corona ${ }^{11}$. Adanya hal tersebut banyak instansi kependidikan swasta maupun negeri baik formal maupun nonformal memberikan kebijakan untuk meliburkan sementara semua kegiatan yang telah diagendakan untuk memutus mata rantai penyebaran Covid-19.

Taman Pendidikan Al-Quran (TPQ) Miftahul Ulum Masjid Al Huda merupakan salah satu lembaga kependidikan yang berfokus pada pembelajaran membaca Al-Quran pada anak-anak dan keagamaan, lembaga ini berada di Jl Gedong Kuning no 24 Yogyakarta, kegiatan pembelajaran dilaksanakan setiap hari senin sampai jumat pada pukul 16:30-17:30. Pada tanggal 15 maret 2020, Badan Koordinasi TKA-TPA Daerah Istimewa Yogyakarta (BADKO) membertahukan kepada seluruh wali santri, Ustadz/ah dan santri TKA-TPA se Daerah Istimewa Yogyakarta untuk meliburkan sementara kegiatan pembelajaran dalam satu pekan mulai tanggal 16 maret 2020 sampai 22 maret 2020. dengan himbauan "selama liburan dimohon santri tadarus dirumah masingmasing" ". Proses pembelajaran diliburkan selama sepekan lalu disusul dengan surat putusan Gubernur DIY yang menetapkan status tanggap Covid-19 ditetapkan mulai tanggal 20 maret 2020.

Ditengah wabah Covid-19 akhirnya TPQ Miftahul Ulum Gedongkuning meliburkan sementara kegiatan belajar mengajar sampai akhir bulan April guna memutus mata rantai penyebaran Covid-19, selain memberi tugas santri-santri di rumah, TPQ Miftahul Ulum Gedongkuning mencoba menjembatani dengan memberi solusi mengaji menggunakan Video Call Whatsaap, dengan begitu anak tidak akan terbebani dengan sangat karena pendidik, orang tua dan anak ikut terlibat langsung dalam pembelajaran mengaji. Wabah Covid-19 membuat banyak instansi nonformal seperti TPA/TPQ yang meliburkan kegiatan belajar untuk memutus mata rantai penyebaran virus dengan memberikan tugas di rumah, lalu tidak ada tindakan lanjut para pendidik untuk memastikan apakah anak benar-benar mengerjakannya atau tidak, hal itu akan membuat anak merasa tidak dipantau sehingga bermalasmalas atau bahkan beban tugas seakan-akan dititik beratkan pada anak sehingga anak merasa berat dalam mengerjakannya. namun di TPQ

\footnotetext{
11 https://yogyakarta.kompas.com/read/2020/03/20/16245451/sultan-hb-x-tetapkanstatus-tanggap-darurat-virus-corona-di-diy, diakses pada 12 April 2020.

12 Broadcast Messege WhatsApp oleh pihak center Badko TKA TPA DIY Ustadz Muhsonef dan M Da'i Iskandar, 15 maret 2020.
} 
Miftahul Ulum Gedongkuning selain memberikan tugas, juga merangkul para wali santri untuk mendampingi dan menyuport putra-putrinya mengaji melalui Video Call Whatsapp untuk sementara waktu ${ }^{13}$. Penelitian ini sangat penting dilakukan untuk meninjau lebih dalam apakah solusi yang diberikan oleh TPQ Miftahul Ulum Gedongkuning benar-benar solutif dan para wali santri mendukung hal tersebut atau sebaliknya.

Berdasarkan uraian di atas pembahasa mengerucut pada masalah di bawah ini: 1) Apa saja kendala Video Call WhatsAap dalam kegiatan mengaji santri TPQ Miftahul Ulum Gedongkuning?. 2) Apa saja dampak Video Call Whats Aap dalam kegiatan mengaji santri TPQ Miftahul Ulum Gedongkuning?

\section{Metode Penelitian}

Peneliti menggunakan metode deskriptif kualitatif, yaitu mengamati segala aktivitas dalam proses pembelajar saat menggunakan aplikasi video call whatsapp, melakukan wawancara kepada ustadz/ah, wali santri dan beberapa santri TPQ Miftahul Ulum yang menjadi objek penelitian, serta menggunakan literatur pustaka sebagai penunjang.

Wawancara mendalam pada para ustadz/ah, wali santri dan santri TPQ Miftahul Ulum gedongkuning Yogyakarta sebagi data utama. sedangkan untuk data sekunder yaitu buku-buku dan jurnal penelitian sebelumnya yang tentunya masih berkaitan dengan penelitian ini.

\section{PEMBAHASAN}

Nama Whats $A p p$ adalah plesetan dari frasa Whats Up yang artinya Apa Kabar ${ }^{14}$. WhatsApp sendiri merupakan pesan lintas platform yang memungkinkan penggunanya bertukar pesan tanpa membayar untuk SMS (Short Messege Service), selama terhubung dengan data internet ${ }^{15}$. Menurut fauzi dalam jurnal Mega dkk, Whats App adalah aplikasi media sosial yang dapat melakukan text/voice, photo sending, document sending,location sending ${ }^{16}$. Whatsaap dengan koneksi internet sangat memungkinkan

\footnotetext{
13 Observasi yang dilakukan pada tanggal 16 Maret 2020.

${ }^{14}$ https://www.whatsapp.com/about/?lang=id diakses pada 13 April 2020 pukul 10.49

15 Hamidah syarif, Dessy Indah, Whatsapp Sebagai Media Strategi Komunikasi Ustadzah Dalam Menyampaikan Dakwah (Studi Deskriptif Kualitatif Komunitas "Belajar Islam Seru”), Universitas Bhayangkara Jakarta Raya, Conferensi Proceeding. Vol 1, No 2, (2018), h, 133.

16 Mega Widhiyasari, Nailariza Umami, Imam Sukwatus Suja'I, Pengaruh Penggunaan Media Sosial Whatsapp Terhadap Keaktifan Siswa Pada Mata Pelajaran Ekonomi Bisnis Kelas X Smk Negeri 2 Boyolangu Tabun Ajaran 2018/2019, Jurnal Pendidikan Ekonomi, Vol.12, No.2, (2019), h, 96.
} 
penggunanya membangun berkomunikasi serta aplikasi instan ini dapat mengirim obrolan, gambar, foto, video secara online ${ }^{17}$.

Berbagai ungkapan definisi di atas, dipahami bahwa Whats App merupakan suatu aplikasi yang berisi fitur mengirim pesan, dokumen, foto, video, audio, kontak serta lokasi kepada seseorang yang juga memiliki aplikasi Whats $A p p$, dan dapat melakukan panggilan telfon maupun video serta banyak fitur penunjang seperti menghias tema/ privasi yang keseluruhan diamankan dengan enkripsi end-to-end serta terhubung dengan internet.

\section{Sejarah Whatsaap}

Acton dan Koum dua orang yang menadi pendongkrak whatsaap, dimana mereka adalah pendirinya setelah berhenti bekerja dari yahoo, suatu ketika mereka membeli iphone dan timbul sebuah inspirasi dan menjajal sebagai developer aplikasi sehingga dia ingin menjual di Aap store $^{18}$. Saat masih merintis Koum sempat frustasi dan menyerah, namun Brian Acton berusaha menguatkan Koum atas usahanya telah sejauh ini, dan mereka mampu bangkit, saat Whats $A p p$ telah mencapai 2.0 telah memiliki 250 ribu user aktif. Kini Lebih dari 2 miliar orang di lebih dari 180 negara menggunakan Whats Aap ${ }^{19}$.

\section{Dampak WhatsAap}

Mutlak adanya bahwa semua yang di dunia terdapat madharat dan manfaat, manusia yang memiliki keistimewaan yaitu memiliki kelebihan dalam membedakan hal positif dan negatif berkewajiban bertindak dengan bijak. Banyaknya pengguna WhatsApp bukan berarti baik seutuhnya, ada sisi-sisi buruk yang patut menjadi pelajaran bagi manusia. Berikut dampak positif dan negatif pada WhatsApp:

1. Dampak positif : 1) tempat berbisnis, 2) tempat bertukar fikiran untuk memecahkan persoalan, 3) Mempererat tali silaturrahmi, 4) ekonomis.

2. Dampak negatif : 1) lupa waktu, Euforia bermedsos ria membuat lupa waktu. 2) tempat penyebaran berita palsu/ Hoax, mudahnya jempol bergerak dan tanpa berfikir panjang, mengakibatkan banyak

\footnotetext{
17 Siti Aisyah, Muhammad Asrori, Yuline, Pengarub Pemanfaatan Whatsapp Terbadap Interaksi Anak Dan Orang Tua Peserta Didik Smpn 10 Pontianak, Universitas Tanjungpura Pontianak,(2018), h, 2.

18 https://www.academia.edu/37212652/Mobile_Computing_System_WhatsApp_pdf. diakses pada tanggal 11 april 2020.

19 https://www.whatsapp.com/about/?lang=id, diakses pada 13 April 2020 pukul 10.49
} 
berita palsu bertebaran, 3) sebagai sarana mesum, banyak fitur-fitur seperti pengiriman foto/ video dll yang disalah gunakan para fiktor.

Beragam fitur dalam WhatsAap seperti menyimpan dokumen dalam bentuk word, pdf, powerpoint membuat aplikasi ini dapat dijadikan alternatif sebagai media dalam pembelajaran, tidak hanya itu, WhatsAap juga dapat meneruskan pesan dari orang lain, hal itu sangat memudahkan jika ingin berbagi cerita dengan kawan. Bahkan jika ingin tatap muka empat mata/ lebih bisa menggunakan layanan video call.

Penelitian saudara Edi Suryadi dkk mengatakan. Disamping itu terlalu sering dalam bermedia sosial seperti whatsaap dapat menjadikan menurunnya kedisiplinan pada peserta didik. ${ }^{20}$. Penelitian tersebut dilaksanakan di dalam kelas yaitu saat proses pembelajaran pendidikan agama islam berlangsung. Sependapat dengan penelitian Siti Aisyah. Pemanfaatan whatsaap pada peserta didik kelas VII SMP Negeri 10 Pontianak tergolong baik, artinya peserta didik aktif dalam menggunakan dan memanfaatkan whatsaap. bahwa pemakaian media sosial seperti whatsaap sangat memungkinkan siswa menggunakannya dalam proses pembelajaran $^{21}$.

pandangan yang hanya satu sisi tanpa melihat sisi-sisi yang lain akan membuat segalanya dalam keterbatasan, jika whatsaap dipandang pada sisi kirinya maka yang terlihat hanya sisi kirinya saja, sedangkan segala sesuatu pasti ada baik dan buruknya, jika kita hanya terfokus pada sisi buruknya maka sisi buruk itu saja yang kita dapatkan, namun jika perlahan menengok kesisi baik dan berusaha memilih dan memilah maka akan mendapatkan manfaatnya. Apalagi zaman sekarang telah dibalut dengan inovasi teknologi yang begitu dahsyat, jika hanya memandang sisi negatif maka akan sangat tertinggal dan tergerus zaman.

\section{Taman Pendidikan Al Quran Miftahul Ulum Gedongkuning}

Peraturan pemerintah nomor 55 pasal 24 ayat 1 tahun 2007 tentang pendidikan agama dan keagamaan menjelaskan bahwa Taman Pendidikan Alquran adalah sebuah lembaga pendidikan keagamaan non formal yang mempunyai tujuan untuk meningkatkan kemampuan peserta didik dalam membaca, menulis, memahami dan mengamalkan

20 Edi Suryadi, M Hidayat, M Priyatna, Penggunaan Media Whatsap Dan Pengarubnya Terbadap Disiplin Belajar Peserta Didik Pada Mata Pelajaran Pendidikan Agama Islam, Edukasi Islam. Jurnal Pendidikan Islam, Vol 7, No 1, (2018), H. 3-4.

21 Siti Aisyah. Pengaruh Pemanfaatan Whatsapp Terbadap Interaksi Anak Dan Orang Tua Peserta Didik Pontianak, Artikel Penelitian, Universitas Tanjungpura Pontianak, (2018), $\mathrm{H}, 7$. 
kandungan Alquran ${ }^{22}$. Aneka ragam jenis pendidikan Alquran yang dikenal dengan sebutan Taman Kanak-kanak Alquran (TKA/TPQ), Taman Pendidikan Alquran (TPA/TPQ), Ta'limul Quran lil Aulad (TQA) dan bentuk lain yang sejenis, saat ini telah tersebar luas di tanah $\mathrm{Air}^{23}$.

Dari uraian di atas dapat dipahami Taman Pendidikan Al Quran adalah instansi kelembagaan kependidikan nonformal yang mengajarkan anak untuk membaca, menulis, memahami serta mengajarkan ilmu keagamaan sehingga anak mendapat bekal menuju pendewasaan dan dapat membumikan AlQuran dalam kehidupan nyata.

TPQ Miftahul Ulum lahir pada tahun 1995 di Masjid Al-Huda Gedongkuning untuk mengakomodasi kebutuhan masyarakat Gedongkuning untuk adanya Pendidikan Keislaman Anak-Anak, Lembaga ini berjalan bertahun-tahun untuk membantu mengatasi Buta Aksara Al-Qur'an khususnya serta umumnya pada Pendidikan Agama Islam sampai saat ini ${ }^{24}$. Lembaga ini berada di Jl Gedong Kuning no 24 Yogyakarta, kegiatan pembelajaran pukul 16;30-17:30 pada hari senin sampai dengan jumat. Selain pembelajaran utama berupa Mengaji dan Menulis Iqro' atau Al-Qur'an, perkembangan berikutnya adalah adanya tambahan materi Pendidikan Agama Islam (PAI) seperti Fikih Ibadah, Aqidah-Akhlak, Kisah Nabi, dan lain-lain. Selain itu, diselenggarakan program ekstrakurikuler seperti Rebana, Latihan MC, Menyanyi Lagu Islami, dan lain-lain. ${ }^{25}$

Adapun kebijakan-kebijakan TPQ Miftahul Ulum tertuang dalam visi misinya yaitu:

Visi: "Terciptanya generasi muslim-muslimah yang handal dalam ilmu membaca serta menulis Al-Quran, berakhlakul karimah, dan berpengetahuan agama Islam yang baik dan benar".

Misi: 1) Mendidik santriwan-santriwati untuk mampu membaca AlQur'an secara Murottal Mujawwad

2) Menanamkan nilai-nilai moral untuk menjadi pribadi sholihsholihah

3) Mendidik santriwan-santriwati untuk mampu memahami dan mengamalkan keilmuan Islam

\footnotetext{
22 http://sultra.kemenag.go.id/file/dokumen.pp.No.55.Tahun.2007, pdf, h,10.

23 Imam Machali, Fia Ainul Munawwaroh, Manajemen Pengembangan Sumber Daya Pendidikan Di Taman Pendidikan Al-Qur'an (TPQ) Al-Hidayah Purwogondo Kalinyamatan Jepara, Jurnal An Nur, Vol 4, No 2, (2014), H,204.

24 Profil TPQ Miftahul Ulum. Arsip Kesekretariatan TPQ Miftahul Ulum Gedongkuning yogyakarta, h, 1

25 Profil TPQ Miftahul Ulum. Arsip Kesekretariatan TPQ Miftahul Ulum Gedongkuning yogyakarta, h, 2.
} 
4) Mendidik santriwan-santriwati untuk mampu menulis arab sesuai kaidah

\section{Kendala Video Call WhatsAap dalam kegiatan mengaji santri TPQ Miftahul Ulum Gedongkuning}

Pada bagian ini peneliti akan memaparkan kendala-kendala yang dihadapi dalam kegiatan mengaji satri TPQ Miftahul Ulum berdasarkan hasil wawancara pada para narasumber, berikut cuplikannya:

Kesulitan VC saat ini yang agake menjadi hambatan hanya signal yang kadang tidak stabil, mungkin selama itu hanya itu saja.

Menurut Darmanto yang menjabat sebagai sie Bimbingan dan Konseling kendala sinyal yang kurang stabil menyebakan kegiatan mengaji terganggu, tersendatnya sinyal sering menjadikan suara terputusputus bahkan terhenti.

Tentu, program ini berjalan dengan beberapa catatan. Program ini dapat berjalan dengan syarat gawai Ustadz-Ustadzah dan Wali Santri harus mendukung, ditambah dengan koneksi sinyal internet yang memadai.

Maka, ketika ada sinyal internet yang terbambat ketika berada di ruangan yang kurang sinyal, atau provider yang kurang mendukung ketika cuaca tidak bersababat, maka program ini terpaksa ditunda dan dicari caranya agar tetap bisa terlaksana. Salah satunya dengan memohon Santri untuk berpindah ruangan agar sinyal internet yang tertangkap lebih baik, mematikan kamera Ustadz-Ustadzah agar koneksi internet tidak. membebani gawai wali santri, dan lain sebagainya.

M Abdul Wahab wakil direktur mengungkapkan bahwa pendidik maupun wali santri disyaratkan memiliki handphone yang mendukung selain itu kestabilan sinyal, ketika sinyal terganggu, pendidik/ santri dapat pindah ke tempat yang mendukung sinyal atau menutup fitur kamera agar sinyal tidak terlalu membebani. Hal yang sama juga diungkapkan oleh beberapa narasumber lainnya. Dan sebagiannya mengeluhkan sangat terbatasnya waktu yang diberikan.

\section{Dampak Video Call WhatsAap dalam kegiatan mengaji santri TPQ Miftahul Ulum Gedongkuning}

Pada sub ini peneliti hendak menjelaskan terkait dampak Video Call Whatsaap dalam kegiatan mengaji santri. Dari kesimpilan wawancara serta pengamatan langsung serta observasi. Media alternatif Video Call Whatsaap ternyata memberikan dampak positif dalam mengaji santri. Selama mengikuti kegiatan mengaji melalui Video Call ternyata menfaatnya jauh lebih efektif dalam situasi genting wabah covid-19 ini. Berikut cuplikan hasil wawancara dengan para narasumber 
Alhamdulillaah, Video Call WhatsApp ini bisa berjalan maksimal dengan apresiasi yang bagus dari Wali Santri, Pengurus TPQ, babkan Pengurus Takmir Masjid Al-Huda Gedongkuning. Hal ini dikarenakan program ini berjalan dua arah sehingga proses mengaji bisa berjalan seperti biasanya, walau tidak perlu tatap muka secara langsung.

Menurut M Abdul Wahab Wakil Direktur TPQ MU, proses mengaji menggunakan video call whatsaap berjalan dengan maksmal dengan mendapat dukungan penuh dari wali santri, pengurus TPQ bahkan pengurus takmir masjid Al-Huda Gedongkuning sehingga kegiatan ini berjalan dengann dua arah dengan komunikasi yang cukup bagus. Begitu juga ungkapan oleh Darmanto Sie Bimbingan dan Konseling menyatakan:

Pemanfaatan video call ini juga termasuk menjadi edukasi bagi kita semua khususnya anak - anak kita bahwa ponsel lebih bisa kita manfaatkan sesuai kegunaan dan salah satunya adalah untuk. media belajar, dan satu manfaat lagi ketika diadakan mengaji online TPQ MU adalab adanya pendampingan para santri dari orang tua wali dan bersinergi dengan para ustadz Ustadzah TPQ MU.

Menurut Darmanto dalam ungkapannya di atas bahwa dengan mengaji melalui video Call Whatsaap juga memberikan edukasi / memperkenalkan pada anak bahwa ponsel dapat dimanfaatkan dengan hal positif salah satunya untuk media belajar dan dalam kegiatan mengaji video call pendidik, wali santri juga ikut terjun langsung sehingga anak tidak merasa terbebani dengan sngat.

Lebih jauh lagi dari hasil wawancara terungkap bahwa pemanfaatan video call whatsaap menjadi pilihan media alternatif hanya saja masingmasing narasumber memiliki manfaat yang bervariasi, beirkut cuplikannya:

Kira-kira ya dapat menfaat bisa lebih lancar ngajinya dan nggak main terus di rumah. Sebelum video call juga diajarin dulu terus jadi lebih hafal dan lancar.

Menurut Sri Wahyuni, Berbeda dengan ketika masuk di kelas, para santri berjumpa dengan banyak temannya seingga berpotensi mereka bermain-main saat proses KBM, sedangkan mengaji menggunakan video call santri fokus mengaji sehinigga apa yang dipelajari cepat dicerna dalam fikiran.

Hal sama juga diungkap oleh Meira Ayu:

Untuk kondisi darurat seperti ini, amat sangat membantu kegiatan mengaji anak, disaat anak $\operatorname{rindu} \mathrm{TP} A$, dengan video call anak merasa punya 
jadwal sendiri dan tetap ingat akan rutinintas mengaji di TP A. orang tua juga aktif mengikuti perkembangan mengaji anak. Anak juga tetap ada jadwal tetap mengaji dan tetap merasa di awasi oleh ustadz di TP A.

Kondisi anak yang berada di rumah saja akan membuatnya jenuh dan merindukan kegiatan-kegiatan yang rutin dilakukan anak seperti saat TPQ, dengan video call dapat membayar kerinduan anak, lebih dari itu anak lebih bertanggung jawab dengan kegiatan mengaji dan merasa diawasi oleh gurunya yang disuport wali santrinya.

\section{PENUTUP}

Pada sub ini peneliti memberikan jawaban dari rumusan masalah:

Kendala video call whatsaap dalam kegiatan mengaji santri TPQ Miftahul Ulum Gedongkuning dari hasil wawancara oleh beberapa informan bahwasanya minimnya waktu mengaji dan ketika mengaji berlangsung kadang-kadang sinyal terganggu yang menyebabkan suara terputus-putus bahkan terhenti sehingga harus bergeser ketempat yang tersedia sinyal stabil atau pendidik/ ustadz/ah mematikan fitur kamera agar sinyal hanya terfokus pada suara.

Komunikasi dua arah dan banyak suport membuat kegiatan ini berjalan dengan baik, dan sangat membantu wali santri dalam perkembangan mengaji anak. Kegiatan ini juga dapat mengenalkan pada anak dalam hal positif, bahwa media Video call whatsaap dapat digunakan dalam ranah pembelajaran dan para wali santri merasa anak lebih fokus mengaji, setelah membaca anak di ingatkan bacaan-bacaan yang kurang tepat/salah dan merasa bertanggung jawab karena diakhir sesi anak diingatkan untuk membaca halaman tadi/ selanjutnya dan akan dicek pertemuan besok.

\section{SARAN}

Penelitian pemanfaatan Video Call Whatsaap difokuskan dan dibatasi pada aspek dampak dan kendala yang dihadapi para santri TPA saat mengaji menggunakan Video Call Whatsaap, untuk itu saran teruntuk calon peneliti yang akan membedah/ mengembangkan penelitian ini lebih dalam, maka disarankan menganalisis dari sisi proses pembelajarannya saat menggunakan Video Call Whatsaap dan dapat memaksimalkan penggunaan video call dengan jumlah maksimal yaitu 6 orang, apakah memenuhi tingkat keefektifan. 


\section{DAFTAR PUSTAKA}

Aisyah, Siti. Muhammad Asrori. Yuline. Pengaruh Pemanfaatan Whatsapp Terhadap Interaksi Anak Dan Orang Tua Peserta Didik Smpn 10 Pontianak, Universitas Tanjungpura Pontianak. 2018.

Aisyah, Siti. Pengaruh Pemanfaatan Whatsapp Terhadap Interaksi Anak Dan Orang Tua Peserta Didik Pontianak. Artikel Penelitian. Universitas Tanjungpura Pontianak. 2018.

Dony Purnama, Muhammad. M Sarbini. Ali Maulida. Implementasi Metode pembelajaran AlQuran Bagi Santri Usia Tamyiz Di Kuttab Al-Fatih Bantarjati Bogor. Bogor: Prosiding Al-Hidayah Pendidkan Agama Islam, 2019.

Fadhlia Septiyanti, Rizka. Syuaebatul Islamiyah. Kusmia. Tiara Ayu Saventy. Zakia Mawaddah. Konsep Al-Qur'an tentang Kecerdasan Anak Dalam Q.S. Luqman Ayat 12- 19. At-Tajdid: Jurnal Ilmu Tarbiyah Universitas Ibnu Khaldun Bogor. 2018.

Fadli Akhmad, Djul. Rahendra Maya. dan Sarifudin. Upaya Orangtua dalam Meningkatkan Minat Baca Al-Qu'an Anak dalam Keluarga (Studi di Masjid Umair bin Abi Waqosh Kampung Batu Gede RT 004 RW 007 Desa Cilebut Barat Kecamatan Sukaraja Kabupaten Bogor). Prosa PAI: Prosiding Al-Hidayah Pendidikan Agama Islam. 2018.

http://sultra.kemenag.go.id/file/dokumen.pp.No.55.Tahun.2007.pdf https://www.academia.edu/37212652/Mobile Computing System-

WhatsApp pdf (diakses pada tanggal 11 april 2020)

https://www.academia.edu/37212652/Mobile Computing System-

WhatsApp pdf

https://www.google.com/amp/s/amp.kompas.com/nasional/read/202 0/03/03/06314981/fakta-lengkap-kasus-pertama-virus-coronadi-indonesia. (Diakses pada 12 April 2020).

https://www.whatsapp.com/about/?lang=id. (diakses pada tanggal 11 April 2020)

Machali, Imam. Fia Ainul Munawwaroh. Manajemen Pengembangan Sumber Daya Pendidikan Di Taman Pendidikan Al-Qur'an (TPQ) Al-Hidayah Purwogondo Kalinyamatan Jepara. Jurnal An Nur. Vol 4. No 2. 2014.

Malik Hatta, Abdul. Pemberdayaan Taman Pendidikan Al-Quran (Tpq) Albusna Pasadena Semarang. Jurnal: Dimas Vol 13. No 2. 2013.

Miladiyah, Andi. Pemanfaatan Whatsapp Messenger Info Dalam Pemberian Informasi Dan Peningkatan Kinerja Pada Sub Bagian Program Pemerintah Provinsi Sulawesi Selatan. Tesis: Ilmu Komunikasi Fakultas Ilmu Sosial dan Ilmu Politik Univeristas Hasanuddin Makassar. 2017. 
Misbahuddin, Ling. Dimensi Keilmuan Dalam Al-Qur'an. Jurnal at Taqaddum. Vol 6. No 2. 2014.

Profil TPQ Miftahul Ulum. Arsip Kesekretariatan TPQ Miftahul Ulum Gedongkuning yogyakarta.

Suryadi, Edi. M Hidayat. M Priyatna. Penggunaan Media Whatsap Dan Pengarubnya Terhadap Disiplin Belajar Peserta Didik Pada Mata Pelajaran Pendidikan Agama Islam. Edukasi Islam. Jurnal Pendidikan Islam. Vol 7. No 1. 2018.

Syarif, Hamidah. Dessy Indah. Whatsapp Sebagai Media Strategi Komunikasi Ustadzah Dalam Menyampaikan Dakwah (Studi Deskriptif Kualitatif Komunitas "Belajar Islam Seru"), Universitas Bhayangkara Jakarta Raya, Conferensi Proceeding. Vol 1. No 2. 2018.

Trisnani. Pemanfaatan Whatsapp Sebagai Media Komunikasi Dan Kepuasan Dalam Penyampaian Pesan Dikalangan Tokoh Masyarakat. Kominfo: Jurnal Komunikasi. Media dan Informatika. Vol 6. No 3. 2017.

Widhiyasari, Mega. Nailariza Umami. Imam Sukwatus Suja'I. Pengaruh Penggunaan Media Sosial Whatsapp Terhadap Keaktifan Siswa Pada Mata Pelajaran Ekonomi Bisnis Kelas X Smk Negeri 2 Boyolangu Tabun Ajaran 2018/2019. Jurnal Pendidikan Ekonomi. Vol.12. No.2. 2019. 